\title{
Integrasi Pendidikan Lingkungan Hidup Pada Pembelajaran Jurusan Perikanan di SMK Negeri 2 Wajo Provinsi Sulawesi Selatan
}

\author{
Muhammad Rusman ${ }^{1)}$, Muzaki ${ }^{2)}$ \\ ${ }^{1)}$ SMK Negeri 2 Wajo \\ ${ }^{2)}$ STMIK Handayani Makassar \\ Email : fikhatarku@hotmail.com
}

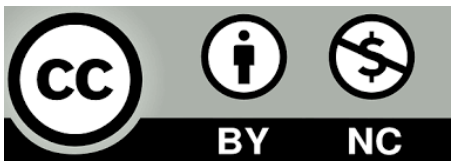

(C) 2020 - UEJ Program Studi Pendidikan Kependudukan dan Lingkungan Hidup

Universitas Negeri Makassar. Ini adalah artikel dengan akses terbuka

dibawah Licensi CC BY-NC-4.0(http:/creativecommons.org/licenses/by-nc/4.0)

\begin{abstract}
Abstrak.
Metode penelitian ini adalah metode deskriptif yang bertujuan untuk mendapatkan materi pembelajaran lingkungan hidup yang dapat diintegrasikan pada pembelajaran jurusan perikanan di SMK Negeri 2 Wajo. Jenis penelitian ini menggunakan penelitian kualitatif karena analisis datanya berupa kata-kata tertulis atau lisan dan mempertimbangkan pendapat orang lain yang disebut narasumber. Beberapa materi pokok pada Kompetensi Dasar (KD) pada kurikulum 2013 mata pelajaran di jurusan perikanan SMK, setelah diidentifikasi dan dianalisa secara mendalam ternyata dapat diintegrasikan beberapa materi tentang pendidikan lingkungan hidup. Penyusunan deskripsi singkat materi integrasi pendidikan lingkungan hidup di jurusan perikanan diarahkan agar ada perubahan pola pengetahuan, kesadaran, sikap, keterampilan dan partisipasi yang diharapkan kepada siswa kedepannya.
\end{abstract}

Kata kunci: Perikanan SMK, Materi integrasi PLH, Lingkungan Hidup

\section{PENDAHULUAN}

Masalah lingkungan yang dihadapi sekarang sudah sangat parah dan oleh karena itu pemecahannyapun tidak cukup hanya dilakukan oleh kelompok tertentu. Masalah lingkungan merupakan masalah seluruh bangsa di dunia terutama di negara-negara berkembang termasuk Indonesia. Pemecahan masalah lingkungan yang dihadapi sekarang bukan hanya tanggung jawab pendidik tetapi juga ahli hukum, dokter, politikus, dan profesi lainnya yang terlibat dalam masalah lingkungan termasuk peneliti. Pemecahan masalah lingkungan bukan hanya merupakan tanggung jawab pemerintahan suatu negara, suatu kota tetapi menjadi tanggung jawab seluruh umat manusia yang hidup di planet bumi ini.

Jika watak manusia tidak dibarengi sentuhan pengetahuan, dan pemahaman tentang pengelolaan lingkungan maka perilaku peduli terhadap permasalahan lingkungan sulit untuk teratasi. Pendidikan Lingkungan Hidup (PLH) merupakan program mata pelajaran pengelolaan lingkungan hidup dirintis sejak Kurikulum Tahun 1984 sampai sekarang, disampaikan dalam bentuk monilitik dan integratif, namun hasil dan dampaknya belum banyak dirasakan terhadap lingkungan dan masyarakat.

Mengacu pada Undang-Undang Nomor 32 Tahun 2009 Pasal 65 poin keempat tentang Perlindungan dan Pengelolaan Lingkungan Hidup, disebutkan bahwa setiap orang berhak dan berperan dalam pengelolaan lingkungan hidup. Hal ini berarti setiap 
individu harus memiliki rasa tanggung jawab terhadap lingkungannya. Berangkat dari filosofi pendidikan sebagai motor penggerak kemajuan bangsa, sekolah diharapkan turut serta mengambil peran dalam pengelolaan lingkungan. Melalui sekolah menengah kejuruan diharapkan mampu menanamkan kesadaran terhadap kepedulian dan kecintaan terhadap lingkungan kepada generasi muda. Penanaman pondasi lingkungan sejak dini menjadi solusi utama yang harus dilakukan, agar generasi muda memiliki pemahaman tentang lingkungan hidup dengan baik dan benar (Sumarmi, 2008). Sullivan di Bezzina (2006) menyatakan bahwa krisis lingkungan merupakan masalah sosial dan bukan semata-mata sesuatu yang alami. Pendidikan Lingkungan Hidup memiliki peran yang sangat penting dalam menangani masalah lingkungan yang muncul saat ini.

Salah satu puncak perkembangan pendidikan lingkungan adalah dirumuskannya tujuan pendidikan lingkungan hidup menurut UNCED adalah sebagai berikut : Pendidikan lingkungan Hidup (environmental education - EE) adalah suatu proses untuk membangun populasi manusia di dunia yang sadar dan peduli terhadap lingkungan total (keseluruhan) dan segala masalah yang berkaitan dengannya, dan masyarakat yang memiliki pengetahuan, ketrampilan, sikap dan tingkah laku, motivasi serta komitmen untuk bekerja sama, baik secara individu maupun secara kolektif, untuk dapat memecahkan berbagai masalah lingkungan saat ini, dan mencegah timbulnya masalah baru [UN - Tbilisi, Georgia - USSR (1977) dalam Unesco, (1978)].

Pendidikan Lingkungan Hidup memasukkan aspek afektif yaitu tingkah laku, nilai dan komitmen yang diperlukan untuk membangun masyarakat yang berkelanjutan (sustainable). Pencapaian tujuan afektif ini biasanya sukar dilakukan. Oleh karena itu, dalam pembelajaran guru perlu memasukkan metode-metode yang memungkinkan berlangsungnya klarifikasi dan internalisasi nilai-nilai. Dalam PLH perlu dimunculkan atau dijelaskan bahwa dalam kehidupan nyata memang selalu terdapat perbedaan nilainilai yang dianut oleh individu. Perbedaan nilai tersebut dapat mempersulit untuk derive the fact, serta dapat menimbulkan kontroversi/pertentangan pendapat. Oleh karena itu, PLH perlu memberikan kesempatan kepada siswa untuk membangun keterampilan yang dapat meningkatkan kemampuan memecahkan masalah.

Pendidikan Lingkungan Hidup dapat diintegrasikan melalui bidang studi di sekolah, Pendidikan Lingkungan Hidup dapat dilaksanakan dengan pendekatan interdisipliner, multidisipliner dan transdisipliner di sekolah ( Barlia, 2008 ). Beberapa penelitian mengungkap pentingnya pendidikan lingkungan hidup, seperti yang dinyatakan Chen (2008) bahwa pendidikan lingkungan merupakan alat yang sangat penting dalam menyediakan pengetahuan, sikap positif terhadap lingkungan serta membangun keterampilan untuk melindungi dan meningkatkan kualitas lingkungan. Melalui pembelajaran pendidikan lingkungan hidup pada kompetensi budidaya perikanan di jurusan perikanan di SMK dirasa sangat tepat dalam mengajarkan Pendidikan Lingkungan Hidup kepada siswa.

Pembelajaran pengelolaan lingkungan hidup masih dibutuhkan siswa SMK bidang keahlian budidaya perikanan untuk peningkatan keterampilan akademik sebelum masuk pada dunia kerja industri, dimana sumber pencemaran lingkungan di akibatkan oleh industri.

Standar kompotensi lulusan Siswa SMK akan dipersiapan mengisi dunia kerja pada industri atau perusahaan, untuk itu saat yang tepat siswa SMK dibekali ilmu pengetahuan pengelolaan lingkungan sebelum mereka memasuki dunia kerja. Menurut. Berdasarkan data empiris, terjadinya kerusakan lingkungan akan dipengaruhi tindakan 
sosial manusia yang tidak terkontrol memungkinkan seorang manusia akan memiliki watak seperti yang dikemukakan di atas.

Urgensi pendidikan lingkungan hidup bagi lulusan SMK terkait dengan pengembangan pengetahuan dan sikap lingkungan yang kedepan menjadi pelaku dalam berbagai industri, perlu dibekali dengan pengetahuan dan keterampilan pengetahuan sumber daya alam yang bijaksana. Dengan bekal tersebut, maka pembangunan berkelanjutan dapat tercapai dengan dukungan potensi sumberdaya manusia. Hal ini sesuai dengan teori (Jorge \& Lucila, 2010) perilaku tanggung jawab lingkungan muncul karena adanya nilai, norma, sikap dan keyakinan. Nilai teridentifikasi dan muncul dalam gaya hidup seseorang sebagai perwujudan dari keyakinan pada sesuatu. Nilai, norma, sikap, dan keyakinan berkaitan dengan keberpihakan pada lingkungan membangun lahirnya perilaku tanggung jawab lingkungan.

Olehnya itu maka kajian ini mengulas tentang pengembangan materi lingkungan yang terdiri dari issue lingkungan serta teknologi ramah lingkungan sebagai solusi dalam landasan pengembangan materi diintegrasikan dalam mata pelajaran produktif jurusan perikanan pada SMK Negeri 2 Wajo

\section{METODE PENELITIAN}

Metode penelitian ini adalah metode deskriptif yang bertujuan untuk mendapatkan materi pembelajaran lingkungan hidup yang dapat diintegrasikan pada pembelajaran jurusan perikanan di SMK Negeri 2 Wajo.

Metode deksriptif adalah suatu metode dalam meneliti sekelompok manusia, suatu objek, kondisi, sistem pemikiran ataupun peristiwa pada masa sekarang. Jenis penelitian ini menggunakan penelitian kualitatif karena analisis datanya berupa katakata tertulis atau lisan dan mempertimbangkan pendapat orang lain yang disebut narasumber.

\section{HASIL DAN PEMBAHASAN}

\section{A. Identifikasi Materi Pembelajaran Lingkungan Hidup}

Fokus mata pelajaran di jurusan perikanan yang akan diidentifikasi materi pembelajaran lingkungan hidup yakni pada kelompok dasar program keahlian yang merupakan bagian dari muatan peminatan kejuruan terdiri dari 3 (tiga) mata pelajaran. Pemilihan fokus pada kelompok dasar program keahlian karena pada kelompok ini merupakan dasar bagi pelajaran kelompok selanjutnya yakni kelompok bidang keahlian. Mata pelajaran pada kelompok dasar program keahlian pada jurusan perikanan yakni dasar-dasar budidaya perikanan, kualitas air dan hama penyakit dan produksi pakan alami dan buatan.

Namun setelah dilakukan identifikasi materi pembelajaran melalui metode pengumpulan dan analisa data, ternyata hanya ada 2 (dua) mata pelajaran yang materi pokoknya dapat diintegrasikan dan relevan dengan materi pendidikan kependudukan dan lingkungan hidup. Mata pelajaran tersebut yakni mata pelajaran dasar-dasar budidaya perikanan dan mata pelajaran kualitas air dan hama penyakit.

Hasil identifikasi materi pembelajaran di jurusan perikanan yang dapat diintegrasikan dengan materi pendidikan kependudukan dan lingkungan hidup yang diperoleh peneliti melalui beberapa metode pengambilan data (observasi, dokumentasi, wawancara dan FGD) di SMK Negeri 2 Wajo untuk mata pelajaran dasar-dasar budidaya perikanan diperoleh data sebagai berikut : 
Tabel 1. Hasil Identifikasi Materi Pembelajaran di Jurusan Perikanan pada Mata Pelajaran Dasar-Dasar Budiaya Perikanan yang dapat Diintegrasikan Pendidikan Kependudukan dan Lingkungan Hidup

\begin{tabular}{|c|c|c|}
\hline No & Kompetensi Dasar & Materi/Sub Materi Pokok Integrasi PKLH \\
\hline 1. & $\begin{array}{l}\text { 1.1. Menjelaskan potensi dan } \\
\text { peran budidaya perairan } \\
\text { berdasarkan sumberdaya } \\
\text { alam, ekonomi dan sosial }\end{array}$ & $\begin{array}{l}\text { - Pengelolaan lingkungan hidup budidaya } \\
\text { ikan } \\
\text { - Budidaya ikan berkelanjutan } \\
\text { - Ekonomi sumberdaya lingkungan }\end{array}$ \\
\hline 2. & $\begin{array}{l}\text { 3.2 Menjelaskan prinsip - prinsip } \\
\text { ekologi pada budidaya perairan }\end{array}$ & $\begin{array}{ll}\text { - } & \text { Polutan } \\
\text { - } & \text { Biodiversitas } \\
\text { Ekosistem pesisir dan daerah aliran } \\
\text { sungai (DAS) } \\
\text { - Pengertian eksostem pesisir dan daerah } \\
\quad \text { aliran sungai (DAS) } \\
\text { - Identifikasi kerusakan lingkungan } \\
\text { pesisir dan daerah aliran sungai (DAS) } \\
\text { - Menyebutkan dampak kerusakan } \\
\text { lingkungan pesisir dan daerah aliran } \\
\text { sungai (DAS) } \\
\end{array}$ \\
\hline & $\begin{array}{l}\text { 3.3 Mengklasifikasikan jenis-jenis } \\
\text { komoditas dan karakteristik } \\
\text { komoditas perairan yang } \\
\text { memiliki nilai ekonomi tinggi } \\
\text { (lokal, regional dan } \\
\text { internasional) }\end{array}$ & - Lingkungan budidaya ikan \\
\hline
\end{tabular}

Hasil identifikasi materi pembelajaran di jurusan perikanan yang dapat diintegrasikan dengan materi pendidikan kependudukan dan lingkungan hidup yang diperoleh peneliti melalui beberapa metode pengambilan data (observasi, dokumentasi, wawancara dan FGD) di SMK Negeri 2 Wajo untuk mata pelajaran kualitas air dan hama Penyakit diperoleh data sebagai berikut :

Tabel 2. Hasil Identifikasi Materi Pembelajaran di Jurusan Perikanan pada Mata Pelajaran Kualitas Air dan Hama Penyakit yang dapat Diintegrasikan Pendidikan Kependudukan dan Lingkungan Hidup

\begin{tabular}{|c|c|c|}
\hline No & Kompetensi Dasar & Materi/Sub Materi Pokok Integrasi PKLH \\
\hline 1. & $\begin{array}{l}\text { 3.1 Mengidentifikasi parameter } \\
\text { kualitas air }\end{array}$ & $\begin{array}{l}\text { - Daya Dukung lingkungan } \\
\text { - Pencemaran air }\end{array}$ \\
\hline 2. & $\begin{array}{l}\text { 3.4. Menganalisis kesesuaian } \\
\text { parameter kualitas air dengan } \\
\text { standar kualitas air yang di } \\
\text { persyaratkan }\end{array}$ & - Sumber-sumber pencemaran air \\
\hline 3. & $\begin{array}{l}\text { 3.5. Menganalisis pengelolaan } \\
\text { kualitas air pada kolam } \\
\text { budidaya }\end{array}$ & $\begin{array}{l}\text { - Pencegahan pencemaran air } \\
\text { - Teknologi ramah lingkungan biofilter }\end{array}$ \\
\hline & 3.7. Menganalisis hubungan antara & - Lingkungan perairan air tawar \\
\hline
\end{tabular}




\begin{tabular}{llc}
\hline No & \multicolumn{1}{c}{ Kompetensi Dasar } & Materi/Sub Materi Pokok Integrasi PKLH \\
\hline $\begin{array}{l}\text { lingkungan (media air), } \\
\text { komoditas dan penyakit pada } \\
\text { biota air }\end{array}$ & $\begin{array}{l}\text { Lingkungan perairan pesisir (Mangrove, } \\
\text { terumbu karang dan padang lamun) }\end{array}$ \\
\hline
\end{tabular}

\section{B. Deskripsi Singkat Materi Pembelajaran Lingkungan Hidup}

Tindak lanjut dari hasil identifikasi materi pembelajaran di jurusan perikanan yang dapat diintegrasikan dengan materi pendidikan kependudukan dan lingkungan hidup yang diperoleh peneliti melalui beberapa metode pengambilan data (observasi, dokumentasi, wawancara dan FGD) di SMK Negeri 2 Wajo tersebut, maka dibuatkan deskripsi singkat dari materi integrasi itu. Lebih jelasnya dapat dilihat pada tabel dibawah ini :

Tabel 3. Deskripsi Singkat Materi Pembelajaran Lingkungan Hidup yang telah diintegrasikan pada mata pelajaran Dasar-Dasar Budidaya Perikanan di Jurusan Perikanan

\begin{tabular}{|c|c|c|c|}
\hline No & $\begin{array}{l}\text { Kompetensi } \\
\text { Dasar }\end{array}$ & $\begin{array}{c}\text { Materi/Sub } \\
\text { Materi Pokok } \\
\text { Integrasi PKLH }\end{array}$ & $\begin{array}{c}\text { Deskripsi Singkat Materi Integrasi } \\
\text { PKLH }\end{array}$ \\
\hline \multirow[t]{3}{*}{1.} & \multirow[t]{3}{*}{$\begin{array}{l}\text { 3.1. Menjelaskan } \\
\text { potensi dan } \\
\text { peran } \\
\text { budidaya } \\
\text { perairan } \\
\text { berdasarkan } \\
\text { sumberdaya } \\
\text { alam, ekonomi } \\
\text { dan sosial }\end{array}$} & $\begin{array}{l}\text { Pengelolaan } \\
\text { lingkungan } \\
\text { hidup } \\
\text { budidaya ikan }\end{array}$ & 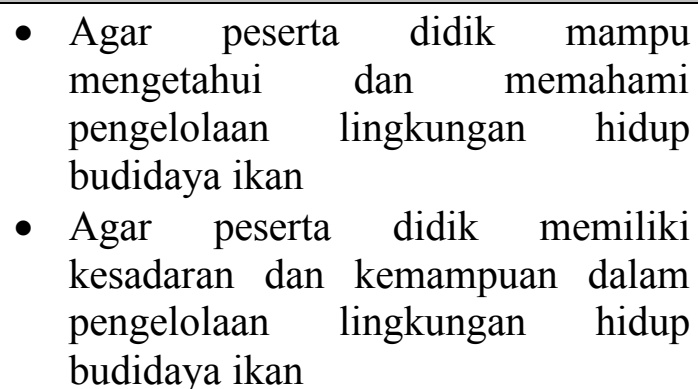 \\
\hline & & 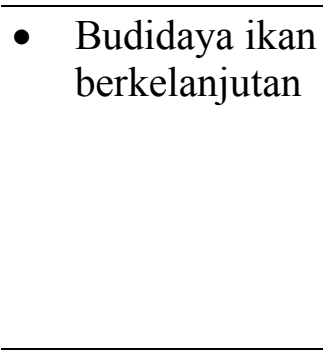 & $\begin{array}{l}\text { - Agar peserta didik mampu } \\
\text { mengetahui dan memahami } \\
\text { budidaya ikan berkelanjutan } \\
\text { - Agar peserta didik memiliki } \\
\text { kesadaran dan kemampuan dalam } \\
\text { mengelola budidaya ikan } \\
\text { berkelanjutan }\end{array}$ \\
\hline & & $\begin{array}{ll}\text { - } & \text { Ekonomi } \\
\text { sumberdaya } \\
\text { lingkungan }\end{array}$ & $\begin{array}{l}\text { - Agar peserta didik mampu } \\
\text { mengetahui dan memahami ekonomi } \\
\text { sumberdaya lingkungan } \\
\text { - Agar peserta didik memiliki } \\
\text { kesadaran dan kemampuan dalam } \\
\text { mengelola ekonomi sumberdaya } \\
\text { lingkungan }\end{array}$ \\
\hline 2. & $\begin{array}{l}\text { 3.2 } \text { Menjelaskan } \\
\text { prinsip- prinsip } \\
\text { ekologi pada } \\
\text { budidaya } \\
\text { perairan }\end{array}$ & Polutan & $\begin{array}{l}\text { - Agar peserta didik mampu } \\
\text { mengetahui dan memahami tentang } \\
\text { polutan } \\
\text { - Agar peserta didik memiliki } \\
\text { kesadaran dan kemampuan } \\
\text { mengelola dalam polutan }\end{array}$ \\
\hline
\end{tabular}




\begin{tabular}{|c|c|c|c|}
\hline No & $\begin{array}{l}\text { Kompetensi } \\
\text { Dasar }\end{array}$ & $\begin{array}{c}\text { Materi/Sub } \\
\text { Materi Pokok } \\
\text { Integrasi PKLH }\end{array}$ & $\begin{array}{c}\text { Deskripsi Singkat Materi Integrasi } \\
\text { PKLH }\end{array}$ \\
\hline & & Biodiversitas & $\begin{array}{l}\text { - Agar peserta didik mampu } \\
\text { mengetahui dan memahami tentang } \\
\text { biodiversitas } \\
\text { - Agar peserta didik memiliki } \\
\text { kesadaran dan kemampuan } \\
\text { mengelola dalam biodiversitas }\end{array}$ \\
\hline & & $\begin{array}{l}\text { Ekosistem pesisir } \\
\text { dan daerah aliran } \\
\text { sungai (DAS) } \\
\text { - Pengertian } \\
\text { eksostem pesisir } \\
\text { dan daerah } \\
\text { aliran sungai } \\
\text { (DAS) } \\
\text { - Identifikasi } \\
\text { kerusakan } \\
\text { lingkungan } \\
\text { pesisir dan } \\
\text { daerah aliran } \\
\text { sungai (DAS) } \\
\text { - Menyebutkan } \\
\text { dampak } \\
\text { kerusakan } \\
\text { lingkungan } \\
\text { pesisir dan } \\
\text { daerah aliran } \\
\text { sungai (DAS) }\end{array}$ & $\begin{array}{l}\text { - Agar peserta didik mampu } \\
\text { mengetahui dan memahami tentang } \\
\text { ekosistem pesisir dan daerah aliran } \\
\text { sungai (DAS) } \\
\text { - Agar peserta didik memiliki } \\
\text { kesadaran dan kemampuan } \\
\text { mengelola ekosistem pesisir dan } \\
\text { daerah aliran sungai (DAS) }\end{array}$ \\
\hline 3. & $\begin{array}{l}\text { 3.3. Mengklasifi- } \\
\text { kasikan jenis- } \\
\text { jenis } \\
\text { komoditas dan } \\
\text { karakteristik } \\
\text { komoditas } \\
\text { perairan yang } \\
\text { memiliki nilai } \\
\text { ekonomi } \\
\text { tinggi (lokal, } \\
\text { regional dan } \\
\text { internasional) }\end{array}$ & $\begin{array}{l}\text { - Lingkungan } \\
\text { budidaya ikan }\end{array}$ & $\begin{array}{l}\text { - Agar peserta didik mampu } \\
\text { mengetahui dan memahami tentang } \\
\text { lingkungan budidaya ikan } \\
\text { - Agar peserta didik memiliki } \\
\text { kesadaran dan kemampuan } \\
\text { mengelola lingkungan budidaya ikan }\end{array}$ \\
\hline
\end{tabular}

Deskripsi singkat mata pelajaran kualitas air dan hama penyakit hasil analisa identifikasi materi yang relevan dengan pembelajaran pendidikan kependudukan dan lingkungan hidup dimaksudkan agar tercapai arah pembelajaran yang 
diinginkan dicapai oleh materi integrasi kepada peserta didik. Lebih jelasnya dapat dilihat pada tabel dibawah ini :

Tabel 4. Deskripsi Singkat Materi Pembelajaran Lingkungan Hidup yang telah diintegrasikan pada mata pelajaran Kualitas Air dan Hama Penyakit di Jurusan Perikanan

\begin{tabular}{|c|c|c|c|}
\hline No & $\begin{array}{l}\text { Kompetensi } \\
\text { Dasar }\end{array}$ & $\begin{array}{c}\text { Materi/Sub } \\
\text { Materi Pokok } \\
\text { Integrasi PKLH }\end{array}$ & $\begin{array}{c}\text { Deskripsi Singkat Materi Integrasi } \\
\text { PKLH }\end{array}$ \\
\hline \multirow[t]{2}{*}{1.} & $\begin{array}{l}\text { 3.1. Mengidentifi- } \\
\text { kasi parameter } \\
\text { kualitas air }\end{array}$ & $\begin{array}{l}\text { Daya Dukung } \\
\text { lingkungan }\end{array}$ & $\begin{array}{l}\text { - Agar peserta didik mampu } \\
\text { mengetahui dan memahami tentang } \\
\text { daya dukung lingkungan } \\
\text { - Agar peserta didik memiliki } \\
\text { kesadaran dan kemampuan } \\
\text { mengelola daya dukung lingkungan }\end{array}$ \\
\hline & & Pence & $\begin{array}{l}\text { - Agar peserta didik mampu } \\
\text { mengetahui dan memahami tentang } \\
\text { pencemaran air } \\
\text { - Agar peserta didik memiliki } \\
\text { kesadaran dan kemampuan } \\
\text { mengelola pencemaran air }\end{array}$ \\
\hline 2. & $\begin{array}{l}\text { 3.4. Menganalisis } \\
\text { kesesuaian } \\
\text { parameter } \\
\text { kualitas air } \\
\text { dengan } \\
\text { standar } \\
\text { kualitas air } \\
\text { yang di } \\
\text { persyaratkan }\end{array}$ & $\begin{array}{l}\text { Sum } \\
\text { penc }\end{array}$ & $\begin{array}{l}\text { - Agar peserta didik mampu } \\
\text { mengetahui dan memahami tentang } \\
\text { sumber - sumber pencemaran air } \\
\text { - Agar peserta didik memiliki } \\
\text { kesadaran dan kemampuan } \\
\text { mengelola sumber - } \\
\text { pencemaran air }\end{array}$ \\
\hline \multirow[t]{2}{*}{3.} & $\begin{array}{l}\text { 3.5. Menganalisis } \\
\text { pengelolaan } \\
\text { kualitas air } \\
\text { pada kolam } \\
\text { budidaya }\end{array}$ & in & $\begin{array}{l}\text { - Agar peserta didik mampu } \\
\text { mengetahui dan memahami tentang } \\
\text { pencegahan pencemaran air } \\
\text { - Agar peserta didik memiliki } \\
\text { kesadaran dan kemampuan } \\
\text { mengelola pencegahan pencemaran } \\
\text { air }\end{array}$ \\
\hline & & $\begin{array}{l}\text { Teknologi ramah } \\
\text { lingkungan } \\
\text { biofilter }\end{array}$ & $\begin{array}{l}\text { - Agar peserta didik mampu } \\
\text { mengetahui dan memahami tentang } \\
\text { teknologi ramah lingkungan biofilter } \\
\text { - Agar peserta didik memiliki } \\
\text { kesadaran dan kemampuan } \\
\text { mengelola teknologi ramah } \\
\text { lingkungan biofilter }\end{array}$ \\
\hline 4. & $\begin{array}{l}\text { 3.7. Menganalisis } \\
\text { hubungan } \\
\text { antara } \\
\text { lingkungan }\end{array}$ & $\begin{array}{l}\text { Lingkungan } \\
\text { perairan air tawar }\end{array}$ & $\begin{array}{l}\text { - Agar peserta didik mampu } \\
\text { mengetahui dan memahami tentang } \\
\text { lingkungan perairan air tawar } \\
\text { - Agar peserta didik memiliki }\end{array}$ \\
\hline
\end{tabular}




\begin{tabular}{|c|c|c|c|}
\hline No & $\begin{array}{l}\text { Kompetensi } \\
\text { Dasar }\end{array}$ & $\begin{array}{c}\text { Materi/Sub } \\
\text { Materi Pokok } \\
\text { Integrasi PKLH }\end{array}$ & $\begin{array}{c}\text { Deskripsi Singkat Materi Integrasi } \\
\text { PKLH }\end{array}$ \\
\hline & \multirow{2}{*}{$\begin{array}{l}\text { (media air), } \\
\text { komoditas } \\
\text { dan penyakit } \\
\text { pada biota air }\end{array}$} & & $\begin{array}{lcc}\text { kesadaran } & \text { dan } & \text { kemampuan } \\
\text { mengelola } & \text { lingkungan } & \text { perairan air } \\
\text { tawar } & & \\
\end{array}$ \\
\hline & & $\begin{array}{l}\text { Lingkungan } \\
\text { perairan pesisir } \\
\text { (Mangrove, } \\
\text { terumbu karang } \\
\text { dan padang } \\
\text { lamun) }\end{array}$ & $\begin{array}{l}\text { - Agar peserta didik mampu } \\
\text { mengetahui dan memahami tentang } \\
\text { lingkungan perairan pesisir } \\
\text { - Agar peserta didik memiliki } \\
\text { kesadaran dan kemampuan } \\
\text { mengelola lingkungan perairan } \\
\text { pesisir }\end{array}$ \\
\hline
\end{tabular}

\section{KESIMPULAN}

Beberapa materi pokok pada Kompetensi Dasar (KD) pada kurikulum 2013 mata pelajaran di jurusan perikanan SMK, setelah diidentifikasi dan dianalisa secara mendalam ternyata dapat diintegrasikan beberapa materi tentang pendidikan lingkungan hidup.

\section{Referensi}

Bezzina, C., Pace, Paul. (2006). School improvement, school effectiveness or scholl development. London: Trentham Books Limited.

Barlia, Lily. 2008. Teori Pembelajaran Lingkungan Hidup di Sekolah Dasar. Subang: Royyan Press.

Chen, Judith., Cheng, Hsuan (2008). Children,Teachers and Nature: An Analysis of An Environmental Education Program. University of Florida.

Sumarmi. 2008. Sekolah Hijau Sebagai Alternatif Pendidikan Lingkungan Hidup Dengan Menggunakan Pendekatan Kontekstual. Jurnal Ilmu Pendidikan Jilid 15 Nomor 1 Halaman 19-25. Malang: LPTK (Lembanga Pendidikan dan Tenaga Pendidikan) dan ISPI (Ikatan Sarjana Pendidikan Indonesia)

UNESCO (1977). Konferensi Tbilisi tentang Pendidikan Lingkungan Hidup. Tbilisi : UNESCO

Valentin, J. and Gamez, L. (2010). Environmental Psychology New Development. New York: Nova Science Publisher. 